\title{
The Danube submarine canyon (Black Sea): morphology and sedimentary processes
}

\author{
Irina Popescu*, a, b, Gilles Lericolais ${ }^{b}$, Nicolae Panin ${ }^{c}$, Alain Normand ${ }^{\text {, }}$, \\ Cornel Dinu ${ }^{\mathrm{d}}$ and Eliane Le Drezen ${ }^{\mathrm{b}}$
}

\author{
a GeoEcoMar Constanta, 304 Mamaia Boulevard, RO-8700, Constanta, Romania \\ b IFREMER Brest, DRO/GM LES, BP 70, F-29280, Plouzané, France \\ c GeoEcoMar Bucharest, 23-25 D. Onciu Street, RO-70318, Bucharest, Romania \\ d University of Bucharest, Faculty of Geology and Geophysics, 6 Traian Vuia Street, PO 37, RO-70139, \\ Bucharest, Romania
}

*: Corresponding author : Present address: Renard Centre of Marine Geology (RCMG), University of Ghent, Krijgslaan 281 S8, B-9000 , Gent, , Belgium. Fax: +32-9-264-49-67

\begin{abstract}
:
The Danube Canyon is a large shelf-indenting canyon that has developed seaward of the late Pleistocene paleo-Danube valley. Mechanisms of canyon evolution and factors that controlled it are revealed by analyzing the morphology and the sedimentary structure of the canyon, as well as the main features of the continental margin around the canyon. This is based on investigation by swath bathymetry in the canyon area combined with different types of seismic data.

The canyon is a major erosional trough with a flat bottom cut by an entrenched axial thalweg. The thalweg path varies from highly meandering to fairly straight in relation to the local gradient. Segments of the canyon are characterized by specific morphology, orientation and gradient along the axial thalweg. We interpret these segments in terms of canyon maturity. The sedimentary structure of the canyon documents an older phase of erosion followed by partial infilling, and thus attests for repeated cycles of canyon development.
\end{abstract}

Canyon morphology is interpreted as a result of erosive sediment flows along the entrenched axial thalweg that caused downcutting into the canyon bottom and instability of the canyon walls, and hence enlargement of the canyon and expansion by headward erosion. During the last lowstand level of the Black Sea the canyon was located in an area of high sediment supply close to the paleo-Danube River mouths. This is indicated by buried fluvial channels on the shelf and by a wave-cut terrace associated with a water level situated about $-90 \mathrm{~m}$ below the present level. We infer that erosive flows in the canyon resulted from hyperpycnal currents at the river mouths, probably favored by the low salinity environment that characterized the Black Sea during lowstand times. Other mechanisms could have contributed to trigger sediment failure along the canyon, such as instability related to the presence of shallow gas, or the effect of a deep fault.

Keywords: Black Sea; submarine canyon; headward erosion; buried fluvial channels; wave-cut terrace; gas 


\section{Introduction}

Submarine canyons are common features on continental margins worldwide. Most of them are located entirely on the upper slope, but there are also a relatively few large canyons with heads that deeply indent the shelfbreak. It was suggested that slope-confined and shelf-indenting canyons represent different stages of canyon evolution, as shelf-indenting canyons had evolved from slope-confined canyons (Twichell and Roberts, 1982), so that breaching the shelfbreak would correspond to the passage from youthful to mature phase in canyon evolution (Farre et al., 1983). The most active canyon development seems to occur in the vicinity of the depocenter areas (Pratson et al., 1994) while shelf-indented canyons commonly connected with the path of a river during lowstand times. This type of connection was largely documented on various continental margins, as for instance Wilmington Canyon and Delaware River (Twichell et al., 1977; Fulthorpe et al., 1999), Hudson Canyon and Hudson River (Fulthorpe et al., 1999), Eel Canyon and the rivers from the northern California coast (Burger et al., 2001) or LacazeDuthiers Canyon and a Pyrenean river (Berné et al., 1999). In some cases, canyons cut into the shelf deposits as far as the modern coastline and reach the river mouths, as Zaire Canyon and Zaire River (Droz et al., 1996, Babonneau et al., 2002) or Canyon of Capbreton and Adour River (Cirac et al., 2001).

A number of these shelf-indenting canyons developed in areas of high sediment delivery through a major river and are associated with large mud-rich deep-sea fan systems in the deep part of the basin (as the Amazon Fan, the Mississippi Fan or the Indus Fan). There is general agreement that canyons acted as the main conduits for transferring river-born sediments towards the deep sea and fed the fan system (Kolla and Coumes, 1987; Weimer, 1990; Flood, Piper, Klaus and Peterson, 1997). Surprisingly enough, little attention has been paid to the structure and evolution of these canyons, despite their essential and well known role in fan 
development, and even though the architecture and sedimentary processes in the corresponding deep-sea fans have been thoroughly studied.

The Danube Canyon (also known as Viteaz Canyon) is a large shelf-indenting canyon located in the north-western Black Sea (Fig. 1). The canyon formed in a zone characterized by major sediment supply during lowstands and is directly connected to the youngest channel-levee system of the Danube fan.

The present paper describes for the first time the detailed morphology and structure of the Danube Canyon and attempts to define sedimentary processes and main controls that acted on its evolution. Our results are based on data collected during the French-Romanian survey in 1998 on the R/V Le Suroit, within the BlaSON (BLAck Sea Over the Neoeuxinian) project initiated by IFREMER and GeoEcoMar (Fig. 2). The SIMRAD EM1000 multibeam echosounder provided the bathymetry and acoustic imagery data that were processed at IFREMER with the CARAIBES software. High-resolution seismic was carried out along the Danube canyon using a mini-GI air-gun seismic source and a twenty-four-channel receiver. Chirp-sonar data were acquired in parallel in order to investigate the surficial sediments. We also used 50 sub-bottom profiles $(3.5 \mathrm{kHz})$ acquired by GeoEcoMar in 1979-1983 on the Romanian shelf, and 10 industrial seismic lines provided by the Romanian company Petrom.

\section{Background}

\subsection{General setting}

The north-western part of the Black Sea is the main depocenter for sediment supply from Central Europe via the Danube River, but also from the Eastern Europe through the Ukrainian rivers Dniepr, Dniestr and Southern Bug (Fig. 1). The shelf is particularly wide in this part of the basin (about $140 \mathrm{~km}$ with a maximum of $170 \mathrm{~km}$ beyond the mouth of the Dniepr River) and narrows to both the east and west (Fig. 1). The shelfbreak is located at water depths of -20- 
140 m southward of the Danube Canyon, and up to -170 m northward of the canyon, possibly due to recent faulting very common in this area.

The continental slope is dissected by numerous canyons, each of which is fed by several tributaries (Fig. 3). These canyons commonly stop at the shelfbreak or slightly upward. The unique and notable exception is the Danube Canyon, a feature that is deeply incised into the shelf for $26 \mathrm{~km}$ landward of the shelfbreak, up to $-110 \mathrm{~m}$ water depth (Fig. 3). The Danube Canyon is the most recent of the major canyons that functioned in this part of the margin and its relief is still preserved in the sea floor morphology, unlike the completely filled up canyons that were identified far landward into the Plio-Quaternary shelf deposits (Lericolais et al., 1998). The Danube Canyon is located on the outer shelf and does not prolong on the upper slope as an erosive trough like the most of the known canyons. Instead, after capturing several tributaries near the shelfbreak, the system continues basinward as a major channel with welldeveloped asymmetric levees. This represents the youngest channel-levee system in the Danube fan and was named the Danube Channel (Popescu et al., 2001; Popescu, 2002). The Danube Canyon is incised by an erosive axial thalweg that maintains beyond the shelfbreak as an entrenched thalweg in the Danube Channel (Fig. 3). Definitely, there is continuity between the mostly erosive Danube Canyon developing on the outer shelf, and the mostly depositional Danube Channel, located on the slope and in the deep basin. The Danube Canyon thus represents the proximal end of this system, and acted as its gateway for the sediment transfer towards the deep sea.

\subsection{Water-level changes}

During highstands the canyon was separated from the coastline by the wide shelf so that the canyon/channel-levee system was mostly inactive. As water level falling partially exposed the shelf, the depocenter moved basinward and river sediment discharge was located on the outer 
shelf. Lowstand periods were thus times of canyon and fan activity. However, it has to be noted that the Black Sea is a marginal basin, connected with the Mediterranean Sea only by the shallow Strait of Bosphorus (currently $32 \mathrm{~m}$ deep). For any water level below this depth, the Black Sea was an isolated basin, and its level oscillated independently from the global eustasy. Consequently, lowstand periods in the Black Sea do not necessarily correspond to lowstands in the world ocean, but are related to regional wet-dry cycles.

Another specificity of the Black Sea basin is that times of isolation were characterised by a low salinity environment due to the absence of marine water influx, as indicated by the associations of fauna in the Black Sea sediments (Jones and Simmons, 1998, Chepalyga, 1985). Canyon and fan active periods are therefore systematically associated with the fresh water phases of the basin, whereas their activity was interrupted during semi-marine to marine highstand phases. The lacustrine conditions are particularly favourable to the generation of quasi-steady hyperpycnal turbidity flows at the river mouths, unlike the marine settings where they occur occasionally (Normark and Piper, 1991; Mulder and Alexander, 2001). During lacustrine lowstands of the Black Sea, hyperpycnal flows potentially directed high-density turbid river waters along the lake bottom over long distances close to the shelf edge and might have influenced the development of the canyons and the initiation of turbidity currents on the slope.

\section{General morphology of the Danube Canyon}

\section{a. Geomorphological analysis}

The Danube Canyon indents the shelf for $26 \mathrm{~km}$ landward of the shelfbreak and follows a slightly sinuous path, with a general NW-SE orientation (Fig. 4).

The canyon consists in an erosional major trough with steep flanks (up to $30^{\circ}$ ). The crest of the canyon walls is affected all over by crescent-shaped scars concave towards the thalweg. This trough is about $6 \mathrm{~km}$ wide near the shelfbreak and narrows landward to $2 \mathrm{~km}$. The flat bottom 
of this main valley is incised by a V-shaped axial thalweg, 400 to $600 \mathrm{~m}$ wide and up to $400 \mathrm{~m}$ deep, that continues beyond the shelfbreak as an entrenched thalweg in the Danube Channel. The morphological features and the orientation vary significantly along the canyon (Figs. 4, 5), as well as the gradient of the channel floor along the axial thalweg (Fig. 6). Accordingly to these variations, five segments can be separated:

- segment $\mathrm{A}$ is a slightly incised zone at the canyon head, up to $-110 \mathrm{~m}$ water depth. It is a 2 $\mathrm{km}$ wide trough with gentle flanks (about $5^{\circ}$ ), oriented NNW-SSE. The axial thalweg is missing.

- segment B is a 3.2 to $4.8 \mathrm{~km}$ wide trough with NW-SE orientation. Flanks are steeper than in segment A but don't exceed $15^{\circ}$. Several distinct paths of the axial thalweg are confined inside the main trough. Gradient profile along each of these paths shows that the youngest channel has the most stable profile (Fig. 4b).

- segment $\mathrm{C}$ is characterised by a 4.8 to $6 \mathrm{~km}$ wide main trough with WNW-ESE orientation. Its flanks are steep $\left(15\right.$ to $\left.30^{\circ}\right)$ and well marked for about $1 \mathrm{~km}$ on each side of the canyon. The bottom of the canyon is relatively flat and incised by a single highly meandering thalweg, 300 to $400 \mathrm{~m}$ wide. The depth of the thalweg below the flat bottom increases basinward from $30 \mathrm{~m}$ to $50 \mathrm{~m}$. The depth of the bottom of the canyon increases as well from $250 \mathrm{~m}$ to $350 \mathrm{~m}$ below the shelf level, so that the total depth of the canyon (including the major valley and the axial thalweg) reaches $400 \mathrm{~m}$ at the distal end of this segment. Abandoned meander paths are common on the flat bottom. Gradient along the axial thalweg is lower than in any other segment $\left(0.31^{\circ}\right)$ and shows irregularities due to transversal bars that locally developed inside the channel (Fig. 6).

- segment D has a NNW-SSE direction and a constant width of $6 \mathrm{~km}$. The gradient of the flanks is $20^{\circ}$ to more than $30^{\circ}$, for $1-2 \mathrm{~km}$ on both sides of the canyon. The single axial thalweg is stable and slightly sinuous. Small lateral tributaries incise the southern side of the 
flat bottom inside the main valley and feed the axial thalweg. The depth of the thalweg is up to $150 \mathrm{~m}$ at the distal end, for a total depth of the canyon of about $600 \mathrm{~m}$. The gradient along the thalweg increases sharply at the transition between segments $\mathrm{C}$ and $\mathrm{D}$ from $0.31^{\circ}$ to $0.47^{\circ}$. - segment E is oriented NW-SE and reaches $6 \mathrm{~km}$ width. The axial thalweg is fairly straight and stable, without lateral gullies. The gradient along the thalweg is $0.34^{\circ}$ - lower than in segment $\mathrm{D}$ which is rather unexpected, and the limit between segments $\mathrm{D}$ and $\mathrm{E}$ is marked by a knickpoint. Flanks are as steep as in segment D and locally join the axial thalweg. Beyond the shelfbreak the system continues as a channel with well-developed lateral levees. The passage between the canyon and the channel along the thalweg profile is marked by a knickpoint (from $0.34^{\circ}$ to $0.71^{\circ}$ ). Downward of this knickpoint the profile becomes concave-up and relatively smooth, as usual in a channel-levee system in equilibrium (Pirmez and Flood, 1995; Torres et al., 1997, Babonneau et al., 2002).

A secondary canyon head can be identified on the upper slope northward of the main canyon. It is $7.7 \mathrm{~km}$ long, 1.2 to $2.4 \mathrm{~km}$ wide and follows a N-S direction up to the $-140 \mathrm{~m}$ isobath. The axial thalweg is $300 \mathrm{~m}$ wide, slightly sinuous in the upper part and rather straight downward. Two other canyon heads of the same type seem to cut into the slope and converge with the main canyon northward of the zone covered by our swath bathymetry, as indicated by shallow seismics and classic bathymetry. The only tributary situated on the southern side of the main canyon is partially filled up and, unlike the other branches, it has no axial thalweg either on its surface or in its deep structure.

\section{b. Interpretation of the morphologic features}

The segments A to E identified along the Danube Canyon and characterised by specific morphology, orientation and gradient, seem to reflect distinct phases of evolution of the canyon by headward erosion. 
The segment A represents the incipient phase of the system. This segment has not an entrenched thalweg and its gentle flanks are not affected by failure scars. It is situated in prolongation of a ramification of the axial thalweg in the segment B that shows the most stable longitudinal profile (path 4 in Figs. 5, 6). This could indicate that the evolution of the canyon (hypothetic because interrupted) would have leaded to the initiation of an entrenched axial thalweg in the segment A.

The segment B is incised by several convergent paths of the axial thalweg ( 1 to 4 in Fig. 5). Longitudinal profile along these paths becomes less steep (therefore more stable) from 4 to 1 . A northward migration of the main channel thalweg seems probable, still it does not necessarily imply the complete abandon of the former paths but rather a gradual decrease of their importance. The canyon wall nearby these incised channels is gentler and less affected by failure scars than the opposite flank. This zone corresponds to a headward erosion phase driven by the downcutting along the unstable channel thalweg, that results in sediment failure at the canyon head.

In segment $\mathrm{C}$ a single meandering thalweg is entrenched between the steep flanks of the canyon. Channel path is unstable as attested by abandoned meanders. The longitudinal depth profile along the channel axis shows that meanders are associated with the lowest gradient zone. Flow energy is low and part of the sediment is deposed either inside the thalweg as channel bars, or laterally on the flat bottom of the canyon. The axial thalweg becomes stable and slightly sinuous to fairly straight in segments D and E. Meanwhile the high gradient along the channel axis enables the quasi-total transfer of the sediment load beyond the shelfbreak. Segments $\mathrm{C}$ to $\mathrm{E}$ can be considered as a mature phase of the canyon, with features that vary along the system as a function of the local gradient. 


\section{Sedimentary structure}

The internal structure of the canyon as indicated by seismic reflection profiles across the canyon shows a major erosional surface at about $240 \mathrm{~m}$ below the bottom of the modern axial thalweg (Fig. 7). The abrupt walls of the major valley are clearly situated in prolongation of this surface in segment $\mathrm{C}$, but also on the south-western flank in the segment $\mathrm{D}$. This indicates that a previous cycle of erosion initiated the formation of the canyon walls currently recognizable in the morphology. Partial infilling of the canyon followed this initial erosional phase. The valley fill consists in a chaotic and relatively transparent facies overlain by a high amplitude bedded facies (Fig. 7). Erosion of the flanks continued during the last active period of the canyon, associated with the functioning of the modern axial thalweg.

The modern canyon thus developed in a morphological context inherited from at least one previous phase. Nevertheless, this system did not limit its activity to transferring sediment through its axial thalweg confined in a relict relief. Downcutting along the thalweg caused instability of the flanks triggering headward erosion of the canyon as in the immature segment B. Erosion in the axial thalweg also resulted in failures enlarging the major valley in the mature segments D and E, directly (on the northern flank) or through a system of lateral gullies (on the southern flank). Segment C is a zone affected by erosion as well: perched terraces were created by failures inside the major valley, while abandoned meanders nearby the canyon walls determined instability and widening of the canyon.

The polyphased evolution of the Danube Canyon is not a unique case. The Mississippi Canyon for instance shows evidence of at least two episodes of deposition and subsequent erosion in the canyon fill sediments (Goodwin and Prior, 1989), whereas the latest Indus Canyon underwent several episodes of cutting and filling as well (Kolla and Coumes, 1987). Many submarine canyons evolved over long time periods from repeated erosional events of varying magnitude (Shepard, 1981). 


\section{Controls on the development of the Danube Canyon}

\section{a. High sediment input}

It has long been observed that many submarine canyons were spatially connected to rivers on the continent (Twichell et al., 1977; Berné et al., 1999; Fulthorpe et al., 1999; Burger et al., 2001). Computer modelling indicated that canyons need not necessarily be linked to specific fluvial sources, still canyon evolution should be most active when sediment influx to the slope is greatest (Pratson and Coakeley, 1996). Hyperpycnal currents generated by the river input can also enhance sediment transport along the sea bottom (Normark and Piper, 1991; Mulder and Alexander, 2001).

Taking into account the location of our study zone in front of one of the largest European rivers, the possible effect of the river sediment supply on the canyon development has to be considered. Nowadays the canyon is situated more than $100 \mathrm{~km}$ far from the Danube mouths. River sediment is trapped by southward currents along the coast and on the inner shelf (Panin, 1996), so that sediment supply is currently interrupted. This was not the case during times of lowstand when part of the shelf was exposed, allowing direct fluvial sediment delivery to the outer shelf, and presumably to the Danube Canyon (Panin, 1989).

In order to clarify the spatial relationship between the river and the canyon, it is critical to recognize (1) the location of the paleo-Danube river and (2) the location of the paleo-shoreline during the last lowstand period in the Black Sea, which was implicitly the last active period of the canyon. Seafloor morphology and shallow stratigraphy of the continental shelf in front of the Danube mouths were investigated with the purpose of tracking buried fluvial chanels - as the diagnostic feature of ancient drainage systems, and wave-cut terraces - generally considered as indicating the proximity of the coastline. 


\section{Paleo-rivers}

Numerous channels have been identified on the continental shelf between -30 and $-90 \mathrm{~m}$ water depth. These channels are erosive structures completely filled up, therefore indistinguishable in the modern bathymetry. They reach 400-1500 m wide and 20-30 m depth, and are sealed only by a thin mud drape parallel to the sea bottom that generally corresponds to Holocene deposits (Fig. 8). There is no independent indication of the age of these incisions, however their stratigraphic position lying directly under the discontinuity at the base of the Holocene strongly suggest they formed during the last level lowstand. Several channels are crossed by each seismic profile, which indicates a braided fluvial system and/or a large number of tributaries. The distribution of the buried channels clusters around two main directions that seem to correspond to two distinct drainage systems (Fig. 9).

The southern system directs straight towards the Danube mouths and most probably represents the paleo-Danube river. Before the construction of the Holocene deltaic edifice the paleoDanube followed a path in prolongation of the modern Sf. Gheorghe arm. On the outer shelf the river seems to split into several arms similar to a fluvial deltaic structure that is comparable in size to the modern Danube Delta and lies close to the Danube Canyon.

The origin of the northern river is uncertain because of the total lack of information concerning its course on the inner Ukrainian shelf. Scherbakov (1978) mapped a river system with more or less the same direction that originated in a small river situated between the Danube and the Dniestr currently flowing in a littoral lagoon, however the question remains open.

\section{Paleo-coastline}

Wave-cut terraces are erosional surfaces created through wave abrasion, thus they indicate the vicinity of the shoreline. A submerged wave-cut terrace was mapped on the outer shelf of the north-western Black Sea for about 100 km (Figs. 9, 10). The terrace wraps around of the head 
of the canyon, still its morphology varies significantly along its path. Southward of the Danube Canyon the wave-cut terrace developed between -98 and $-112 \mathrm{~m}$ water depth and clearly truncates the low angle clinoforms of a prograding facies (Fig. 10). The depth of the terrace gradually decreases when approaching the canyon up to about $-90 \mathrm{~m}$. Behind the head of the canyon the terrace is even shallower and significantly less marked (only 5-6 m height), so that its path is uncertain. Northward of the Danube Canyon the terrace deepens again to $-97 \mathrm{~m}$ while the height increases to $10-15 \mathrm{~m}$, and splits into two distinct steps. The variable depth of the terrace seems to be related to the presence of the canyon since the terrace is clearly shallowest around the canyon head. Moreover, a similar variation of the depth of the terraces was noticed in the northern part of the Black Sea basin (Major, 2002). This could be the effect of the redistribution of the wave energy by refraction when approaching a shoreline, which focus energy on promontories and disperse it in gulfs.

The last lowstand paleo-coastline should thus have been situated between this submerged terrace and the deepest buried fluvial channels (Fig. 9).

The topic of the last lowstand level of the Black Sea has been recently questioned, relatively to the highly debated topic of the catastrophic flood that followed this lowstand, proposed by Ryan et al. (1997). The majority of Russian authors indicated a sea level fall at about $-90 \mathrm{~m}$ depth, based on the location of the offshore sand ridges that formed at the shelf edge south of the Crimea during what they called the Neoeuxinian period; overdeepenings of valley rivers could suggest a maximum level fall to about $-110 \mathrm{~m}$ (Chepalyga, 1985 and references therein). More recent studies proposed a depth of $-105 \mathrm{~m}$, according to a regional erosional truncation on the southern coast of the Black Sea (Demirbağ et al., 1999; Görür et al., 2001) but also based on a terrace on the northern shelf edge (Major, 2002). In contrast, some authors suggested that the lowstand level of the Black Sea reached $-150 \mathrm{~m}$ depth, mainly founded on a regional discontinuity on the northern shelf and considered a sub-aerial erosion surface (Ryan 
et al., 1997) and by features described as shoreline deposits on the margin of Turkey (Ballard et al., 2000).

Our data do not provide any indication of a shoreline at $-150 \mathrm{~m}$, either in the Danube Canyon or along the shelf edge. Instead, they do show (1) a great number of buried fluvial channels on the shelf that suddenly disappear below $-90 \mathrm{~m}$ depth, and (2) a unique wave-cut terrace on the outer shelf, with an upper surface varying between -90 and $-98 \mathrm{~m}$. This is consistent with a major lowstand level situated somewhere around $-90 \mathrm{~m}$ depth.

Consequently, during the last water lowstand the Danube Canyon clearly evolved in a shallow environment affected by high sediment supply. The paleo-coastline was forming a wide gulf in which two rivers were flowing. The canyon was entirely submerged and situated in the southern part of this gulf, in front of the paleo-Danube mouths and below the base of the waveaction zone, as attested by the position of the wave-cut terrace.

Meanwhile, it should be noted that the canyon developed under freshwater conditions. As known, fluvial discharge into a lacustrine basin is likely to create quasi-steady hyperpycnal flows (Normark and Piper, 1991; Mulder and Alexander, 2001). These currents are due to the high density of the turbid river waters penetrating into lower density lake waters, and direct fluvial sediment load along the lake bottom. The short distance between the river mouths and the canyon head, under environmental conditions that particularly favour the formation of hyperpycnal currents suggests that the high sedimentary influx via the paleo-Danube was a major control on the canyon development.

\section{b. Structural control}

It is well established that submarine canyons evolution may be governed by a predominant structural control, especially along active continental margins (Shepard, 1981). This was for instance the case for the San Antonio Canyon on the central Chile margin (Laursen and 
Normark, 2002), for the Tenryu Canyon off central Japan (Soh and Tokuyama, 2002), but also for a number of canyons in the northern Mediterranean (Berné et al., 1999). In the same way, the geometry of the canyon of Capbreton on the eastern Atlantic margin, consisting in a succession of segments with different orientations, was associated with the structural background controlled by a network of faults (Cirac et al., 2001). The Danube Canyon displays the same type of geometry consisting of segments with distinct orientation, but the possible relationship between the changing direction along the canyon and the local tectonics remains unclear.

Nevertheless, as observed by Wong et al. (1994), the Danube Canyon is situated along the prolongation of the Peceneaga-Camena fault, a major crustal fault that represents the tectonic contact between the North Dobrogea Orogen and the Moesian Platform (Fig. 9). This fault is supposed to have played a major role in the evolution of the Western Black Sea basin (Banks and Robinson, 1997) and it corresponds to the south-eastern extremity of the TornquistTeisseyre Line that separates the stable Fennoscandian-East European craton and the fragmented West-European Platform (Hippolyte, 2002). The fault that outcrops on land is buried offshore by thick sedimentary series since the upper Paleogene (Ionescu et al., 2002). The location of the fault on the outer shelf is poorly defined, still some authors have proposed a trajectory that follows the Danube Canyon (Winguth et al., 2000; Dinu et al., 2002; Fig. 9). Although it is currently uncertain if the Peceneaga-Camena fault is indeed located under the Danube Canyon so it could have influenced its development by creating instability on a preferential direction, this possibility cannot be excluded.

\section{c. Gas-related instability}

The shelfedge of the north-western margin of the Black Sea contains evidence of abundant shallow gas and represents a zone of high fluid discharge (Vassilev and Dimitrov, 2000). 
Numerous gas seeps have been identified in this area (Egorov et al., 1998; Fig. 11). Most of them are located inside the Danube Canyon and along the landward prolongation of the canyon. The tributaries that converge with the Danube Canyon on the upper slope correspond to gas escapes zones as well, both the northern one (which is incised by an axial thalweg) and the southern one (without any erosive thalweg inside). Gas seeps were also identified along the shelfbreak, on sub-recent faults north of the canyon, on the upper slope or in the upper Danube channel, usually related to failure areas.

Gas-related features observed on our seismic profiles include acoustic turbidity and blanking beneath the canyon (Fig. 12) but also along its prolongation, commonly corresponding with the spatial distribution of the gas seeps. The gas area along the canyon has a limited lateral extent (Fig. 12), so that the presence of the gas escape zones inside the Danube canyon is not due to exposure of a widespread shallow gas zone to the seafloor through erosion. In addition, the alignment of the gas seeps follows the same direction landward of the canyon, which could be in relation with compression along a regional fault (thus a possible indication for a deep fault under the canyon) or with sediment infilling along a buried canyon head described in that region by Lericolais et al. (1998) and Popescu (2002). Even though the origin of the shallow gas is still uncertain, it seems probable that the location of the gassy facies could have favoured instability in the canyon area and possibly triggered sediment failures, as it does on the upper part of the Danube Channel (Popescu, 2002). The southern tributary of the canyon, not incised by an axial thalweg, could be due exclusively to this type of instability. Moreover, the Dniepr Canyon developed in the northern Black Sea basin in another zone marked of extensive gas escape from the seabed (Egorov et al., 1998), which suggests the importance of this type of instability in the development of a canyon. 


\section{Discussion: origin of the canyon}

The convergence of the main valley of a slope canyon with several closely spaced tributaries is a common pattern on the continental margins worldwide, including the north-western Black Sea slope (Fig. 3). This morphology is referred to as "pinnate drainage" and is considered to reflect the youthful phase in submarine canyon evolution (Farre et al., 1983). The remarkable particularity of the Danube Canyon consists in the preferential development of one of the tributaries, which breached the shelfbreak and deeply indented the continental shelf. Breaching the shelfbreak by a retrogressive canyon is considered to represent the passage from youthful to mature phase of development (Twichell and Roberts, 1982; Farre et al., 1983; Pratson and Coakley, 1996). The Danube Canyon is thus the only canyon that reached a mature phase, unlike its tributaries or any other canyon in this part of the margin.

The five distinct segments of the canyon, characterised by specific morphology, orientation and gradient, seem to reflect the phases of canyon advancement towards the coast. Therefore we suggest that they represent zones of different maturity along the mature Danube Canyon. Things are complicated by the evolution of the modern Danube canyon in the morphologic background inherited from at least one former canyon, only partially infilled. Features generated by this previous stage of canyon development are still recorded in the present morphology, but they are clearly reworked during the modern phase. The Danube Canyon is thus a complex structure that has reached its mature stage through cyclic development.

\section{Sedimentary processes}

The earliest studies of the submarine canyons suggested that they were subaerial river beds submerged during rising sea level at the end of glaciations (Spencer, 1903; Shepard, 1934). The question of the canyon origin was fundamentally re-evaluated ever since, as new techniques became available (for a detailed review see Pratson et al., 1994). Currently, it is 
generally considered that submarine canyons formed either (1) by sediment-flow-driven retrogressive failure usually related to a sediment source on land, or (2) through retrogressive slides induced by slope destabilization associated with a variety of processes.

Geomorphological features of the Danube Canyon discussed above are obviously the result of powerful erosive sediment flows. The entrenched axial thalweg functioned as the "active zone" along the canyon, where sediment flows downcut into the flat canyon bottom. Progressively increasing entrenchement of the thaweg caused destabilization and sediment failures both laterally on the canyon flanks, and at the canyon headwall. Consequently, canyon widened with time, and also penetrated farther into the shelf by headward erosion along sediment flow path towards the source of the flow.

As shown, palaeo-Danube River discharged in the vicinity of the canyon during the last Black Sea level lowstand that corresponds to the last active period of the canyon, under freshwater conditions particularly favourable to initiation of hyperpycnal flows. We assume that sediment flows related to the palaeo-Danube River supply represented the main control on the canyon development.

Other mechanisms could have acted independently but complementarily to promote sediment failure along the Danube Canyon. Instability due to the presence of shallow gas in sediments possibly contributed to cause failures inside the Danube Canyon or along its tributaries on the upper slope. This control seems even more likely on the southern tributary, that does not display an axial thalweg to attest for sediment-flow-driven erosion, but corresponds to a gas escape zone. The influence of fault-controlled instability is presently uncertain but it represents a possibility that has to be considered.

This pattern is significantly different from those proposed for the formation of the Mississippi Canyon (Coleman et al., 1983), the Indus Canyon (Kolla and Macurda, 1988) or even the Danube Canyon (Wong et al., 1994). These authors supposed that canyons originated mainly 
by mass slumping on the continental slope at a location corresponding to a huge depocenter, and grew by subsequent retrograde slumping, during the following rise in sea level. We do not believe that this was the case in the Danube Canyon. Our results indicate that canyon evolution was primarily related to erosion by sediment flow generated at the river mouths during low sea levels, in agreement with the mechanism previously suggested by Shepard (1981), Pratson et al. (1994) and Pratson and Coakeley (1996). As shown above, complementary factors could have joint as well.

The big unknown of the canyon evolution remains the age of this system. Currently, there is no independent age information either on the Danube Canyon incision and infill or on the fluvial buried channels we identified on the shelf. We can only assume that:

(1) The Danube Canyon is the most recent canyon that developed in this part of the margin and its relief is preserved in the sea-floor morphology covered only by the Holocene deposits, therefore it is was (still) functioning during the last lowstand level of the Black Sea. As a general rule, sea-level lowstands in the Black Sea do not necessarily correspond to global lowstands. The last sea-level lowstand in the Black Sea in particular, known as the "Neoeuxinian" was generally considered as matching to the marine isotope stage 2 (Chepalyga, 1985 and references therein), but this correspondence was recently questioned (Major, 2002). The canyon was thus active during the last lowstand, but the age of this period is still uncertain. (2) Buried fluvial incisions on the shelf are sealed only by the thin Holocene blanket, so that they formed during the last sea-level lowstand. Consequently, they are coeval to the youngest phase of canyon evolution.

(3) The evolution of the canyon is related to the evolution of the Danube Channel, since they are parts of a unique canyon-channel system that acted as a whole. Previous estimates of the age of the Danube Channel (Popescu et al., 2001) were based on the correlation of the fan sequences with the sea-level curve (Wong et al., 1994; Winguth et al., 2000) but the proposed 
Neoeuxinian age proved incorrect (Popescu, 2002). The Danube Channel was active during the last lowstand but also earlier, as indicated by ${ }^{14} \mathrm{C}$ datations in the distal part of this system $(\mathrm{C}$. Strechie, in prep.).

Consequently, it is conceivable that the youngest phase of evolution of the Danube Canyon corresponded to the last lowstand of the Black Sea, but canyon formation has also undergone previous stages. Unfortunately, age constraints for the canyon initiation are currently nonexistent, and further investigation is necessary to solve this problem.

\section{Conclusions}

The Danube Canyon is a major erosional feature, deeply indenting into the shelf edge unlike any other canyon in this part of the margin. The canyon consists of a main trough with steep flanks and a flat bottom incised by an entrenched thalweg. Our study suggests that sections of the canyon reflect phases of landward expansion of the canyon, as the distal part of the canyon reached a mature phase while the canyon head is in an incipient stage of erosion. The sedimentary structure of the canyon shows evidence of a previous cycle of erosion followed by partial infilling, and subsequently reincised by the modern canyon. Thus the canyon has not undergone a single-phase catastrophic formation, but a cyclic evolution with at least two erosional cycles of varying magnitude.

On the basis of the geomorphological analysis, we propose that the main mechanism for canyon development was the sediment-flow-driven retrogressive failure. Sediment flows were most probably generated as high-density currents at the mouths of the palaeo-Danube River, favoured by the low salinity conditions of the Black Sea basin. The high sediment influx in this part of the margin was therefore a major control on the canyon development, but other complementary controls (gas-related instability, control by a deep fault) could have contributed as well. 
The Danube Canyon is connected to the Danube Channel, the youngest channel-levee system on the Danube fan that extends between the shelfbreak and the abyssal plain at $2200 \mathrm{~m}$ depth. The canyon represents the upper end of this system and acted as a gateway for transferring sediments between the shelf and the deep basin. High river discharge in the vicinity of the canyon, documented for the youngest phase of the canyon evolution, with probable hyperpycnal flow at the river mouths, suggests that a quasi-continuous river-canyon-fan channel system functioned in this part of the margin, ensuring highly effective transfer of the terrigen sediment towards the deep sea.

\section{Aknowledgements}

The BlaSON French-Romanian project was funded by IFREMER with the collaboration of GeoEcoMar. I.P. acknowledges the Ph.D. funding from the French Government and the active support of the French Embassy in Romania (Service de coopération et d'action culturelle). Discussions with Jean-Louis Olivet contributed substantially to the ideas expressed in this paper. The Romanian company Petrom is thanked for making available a number of seismic profiles for this study.

\section{References}

Babonneau, N., Savoye, B., Cremer, M., Klein, B. (2002). "Morphology and architecture of the present canyon and channel system of the Zaire deep-sea fan". Marine and Petroleum Geology 19: 445-467.

Ballard, R. D., Coleman, D.F., Rosenberg, G.D. (2000). "Further evidence of abrupt Holocene drowning of the Black Sea shelf.” Marine Geology 170: 253-261. 
Banks, C. J., Robinson, A.G. (1997). Mesozoic strike-slip back-arc basins of the western Black Sea region. In: A. G. Robinson (Ed.), Regional and petroleum geology of the Black Sea and surrounding region: 53-62.

Berné, S., Loubrieu, B., et l'équipe Calmar embarquée (1999). "Canyons et processus sédimentaires récents sur la marge occidentale du golfe du Lion. Premiers résultats de la campagne Calmar.” C.R. Acad. Sci. Paris 328: 471-477.

Burger, R. L., Fulthorpe, C.S., Austin Jr, J.A. (2001). "Late Pleistocene channel incisions in the southern Eel River Basin, northern California: implications for tectonics vs. eustatic influences on shelf sedimentation patterns." Marine Geology 177: 317-330.

Chepalyga, A. L. (1985). Inland sea basins. In: A. A. Velichko (Ed.), Late Quaternary environments of the Soviet Union. University of Minnesota Press, Minneapolis: 229-247.

Cirac, P., Bourillet, J.-F., Griboulard, R., Normand, A., Mulder, T. et l'équipe Itsas (2001). "Le canyon de Capbreton: nouvelles approches morphostructurales et morphosédimentaires. Premiers résultats de la campagne Itsas." C.R. Acad. Sci. Paris, Sciences de la Terre et des planètes 332: 447-455.

Demirbag, E., Gokasan, E., Oktay, F.Y., Simsek, M., Yuce, H. (1999). “The last sea level changes in the Black Sea: evidence from the seismic data." Marine Geology 157: 249-265.

Coleman, J. M., Prior, D. B., Lindsay, J. F. (1983). “Deltaic influences on shelf edge instability processes. In: Stanley, D. J. and Moore, G. T. (Eds.), The shelf break: critical interface on continental margins, SEPM Special Publication 33: 121-137.

Demirbağ, E., Gokasan, E., Oktay, F.Y., Simsek, M., Yuce, H. (1999). “The last sea level changes in the Black Sea: evidence from the seismic data." Marine Geology 157: 249-265. Dinu, C., Wong, H. K., Țambrea, D. (2002). "Stratigraphic and tectonic synthesis of the Romanian Black Sea shelf and correlation with major land structures". In: Dinu, C. and 
Mocanu, V. (Eds.), Geology and tectonics of the Romanian Black Sea shelf and its hydrocarbon potential. BGF Special Volume no. 2: 101-117.

Droz, L., Rigaut, F., Cochonat, P., Tofani, R. (1996). "Morphology and recent evolution of the Zaire turbidite system.” GSA Bulletin 108(3): 253-269.

Egorov, V. N., Luth, U., Luth, C., Gulin, M.B. (1998). Gas seeps in the submarine Dnieper canyon, Black Sea: acoustic, video and trawl data. In: U. Luth, C. Luth, H. Thiel (Eds.), MEGASEEBS (Methane Gas Seep Explorations in the Black Sea), Project Report. Hamburg. Berichte aus dem ZMK, Reihe E: 11-21.

Farre, J. A., McGregor, B.A., Ryan, W.B.F., Robb, J.M. (1983). "Breaching the shelfbreak: passage from youthful to mature phase in submarine canyon evolution." SEPM Special Publication 33: 25-39.

Flood, R.D., Piper, D.J.W., Klaus, A., Peterson, L.C. (1997). Proc.ODP, Sci. Results. 155: College Station, TX (Ocean Drilling Program).

Fulthorpe, C. S., Austin Jr., J.A., Mountain, G.S. (1999). "Buried fluvial channels off Nedw Jersey: did sea-level lowstands expose the entire shelf during the Miocene?" Geology 27(3): 203-206.

Goodwin, R. H., Prior, D. B. (1989). “Geometry and depositional sequences of the Mississippi Canyon, Gulf of Mexico”. Journal of sedimentary petrology 59(2) : 318-329.

Görür, N., Cagatay, M.N., Emre, O., Alpar, B., Sakinç, M., Islamoglu, Y., Algan, O., Erkal, T., Keçer, M., Akkok, R., Karlik, G. (2001). "Is the abrupt drowning of the Black Sea shelf at 7150 yr BP a myth?” Marine Geology 176: 65-73.

Hippolyte, J.-C. (2002). "Geodynamics of Dobrogea (Romania): new constraints on the evolution of the Tornquist-Teisseyre Line, the Black Sea and the Carpathians". Tectonophysics 357: $33-53$. 
Ionescu, G., Sisman, M., Cataraiani, R. (2002). "Source and reservoir rocks and trapping mechanisms on the Romanian Black Sea shelf'. In: Dinu, C. and Mocanu, V. (Eds.), Geology and tectonics of the Romanian Black Sea shelf and its hydrocarbon potential. BGF Special Volume no. 2: 67-83.

Jones, R. W., Simmons, M.D. (1997). A review of the stratigraphy of eastern Paratethys (Oligocene-Holocene), with particular emphasis on the Black Sea. In: A.G. Robinson (Ed.), Regional and petroleum geology of the Black Sea and surrounding region. AAPG Memoir 68: $39-52$.

Kolla, V., Coumes, F. (1987). "Morphology, internal structure, seismic stratigraphy, and sedimentation of the Indus fan”. AAPG Bulletin, 71: 650-677.

Kolla, V., Macurda Jr., D. B. (1988). "Sea-level changes and timing of turbidity-current events in deep-sea fan systems”. In: C.K. Wilgus, B.S. Hastings, C.G.St.C. Kendall, H. Posamentier, C.A. Ross, J.C. Van Wagoner (Eds.), Sea-level changes: an integrated approach. SEPM Special Publication 42: 381-392.

Laursen, J., Normark, W. R. (2002). "Late Quaternary evolution of the San Antonio Submarine Canyon in the central Chile forearc $\left(\sim 33^{\circ} \mathrm{S}\right)$ ". Marine Geology, $188: 365-390$.

Lericolais, G., Panin N., Popescu I., Berne S., Ion G., and BlaSON scientific crew (1998). Danube and Dniepr paleovalleys: New discoveries during BlaSON survey on the north-western Black Sea shelf. 3rd International Conference on the Petroleum Geology and Hydrocarbon Potential of the Black and Caspian Seas Area. Neptun, Constanta (Romania). Geo-Eco-Marina 3 (suppl.): 34.

Major, C. O. (2002). Non-eustatic controls on sea-level change in semi-enclosed basins, Ph. D. Thesis, Columbia University: 223 p.

Mulder, T., Alexander, J. (2001). "The physical character of subaqueous sedimentary density flows and their deposits.” Sedimentology 48: 269-299. 
Normark, W. R., Piper, D.J. (1991). Initiation processes ad flow evolution of turbidity currents: implications for the depositional record. From shoreline to abyss, SEPM Special Publications. 46: 207-229.

Panin, N. (1989). “Danube Delta. Genesis, evolution and sedimentology.” Rev. Roum. Géol., Géophys., Géogr., Géographie 33: 25-36.

Panin, N. (1996). "Danube Delta: genesis, evolution, geological setting and sedimentology." Geo-Eco-Marina 1: 7-23.

Pirmez, C., Flood, R. D. (1995). “Morphology and structure of Amazon Channel”. In: Flood, R. D., Piper, D. J. W., Klaus, A., et al., Proceedings of the Ocean Drilling Program, Initial Reports, 155: 23-45.

Popescu, I. (2002). “Analyse des processus sédimentaires récents dans l'éventail profond du Danube (Mer Noire)", Ph. D. thesis, Université de Bretagne Occidentale, 282 p.

Popescu, I., Lericolais, G., Panin, N., Wong, H.K., Droz, L. (2001). “Late Quaternary channel avulsions on the Danube deep-sea fan." Marine Geology 173: 25-37.

Pratson, L. F., Coakley, B.J. (1996). "A model for the headward erosion of submarine canyons induced by downslope-eroding sediment flows.” GSA Bulletin 108(2): 225-234.

Pratson, L. F., Ryan, W. B. F., Mountain, G. S., Twichell, G. S. (1994). "Submarine canyon initiation by downslope-eroding sediment flows: Evidence in late Cenozoic strata on the New Jersey continental slope”. GSA Bulletin 106: 395-412.

Ryan, W. B. F., Pitman, W.C., Major, C.O., Shimkus, K., Moskalenko, V., Jones, G.A., Dimitrov, P., Gorur, N., Sakinç, M., Yuce, H. (1997). "An abrupt drowning of the Black Sea shelf." Marine Geology 138: 119-126.

Scherbakov, F. A., Kuprin, P.N., Potapova, L.I., Polyakov, A. S., Zabelina, E. K., Sorokin, V. M. (1978). Sedimentation on the continental shelf of the Black Sea. Nauka Press, Moscow: 211 p. 
Soh, W., Tokuyama, H. (2002). "Rejuvenation of submarine canyon associated with ridge subduction, Tenryu Canyon, off Tokay, central Japan”. Marine Geology, 187: 203-220.

Shepard, F. P. (1934). "Canyons off the New England coast”. American Journal of Science, 27: 24-36.

Shepard, F. P. (1981). "Submarine canyons: multiple causes and long-time persistence". AAPG Bulletin, 65:1062-1077.

Spencer, J. W. (1903). "Submarine valleys off the American coasts and in the North Atlantic". GSA Bulletin, 14: 207-226.

Torres, J., Droz, L., Savoye, B., Terentieva, E., Cochonat, P., Kenyon, N.H., Canals, M. (1997). "Deep-sea avulsion and morphosedimentary evolution of the Rhone Fan Valley and Neofan during the Late Quaternary (north-western Mediterranean Sea).” Sedimentology 44: 457-477.

Twichell, D. C., Knebel, H.J., Folger, D.W. (1977). "Delaware river: evidence for its former extension to Wilmington submarine canyon." Science 195: 483-485.

Twichell, D.C., Roberts, D.G., 1982. Morphology, distribution, and development of submarine canyons on the United States Atlantic continental slope between Hudson and Baltimore Canyons. Geology, v. 10, p. 408-412.

Vassilev A., Dimitrov, L. (2000). "Spatial and quantity evaluation of the Black Sea gas hydrates". Proceedings of the $6^{\text {th }}$ Conference "Gas in Marine Sediments", St. Petersburg, Russia.

Weimer, P. (1990). "Sequence stratigraphy, facies geometries, and depositional history of the Mississippi Fan, Gulf of Mexico”. AAPG Bulletin 74 (4), 425-453.

Winguth, C., Wong. H.K., Panin, N., Dinu, C., Georgescu, P., Ungureanu, G., Krugliakov, V.V., Podshuveit, V. (2000). "Upper Quaternary water level history and sedimentation in the northwestern Black Sea.” Marine Geology 167: 127-146. 
Wong, H. K., Panin, N., Dinu, C., Georgescu, P., Rahn, C. (1994). "Morphology and postChaudian (Late Pleistocene) evolution of the submarine Danube fan complex.” Terra Nova 6: 502-511. 


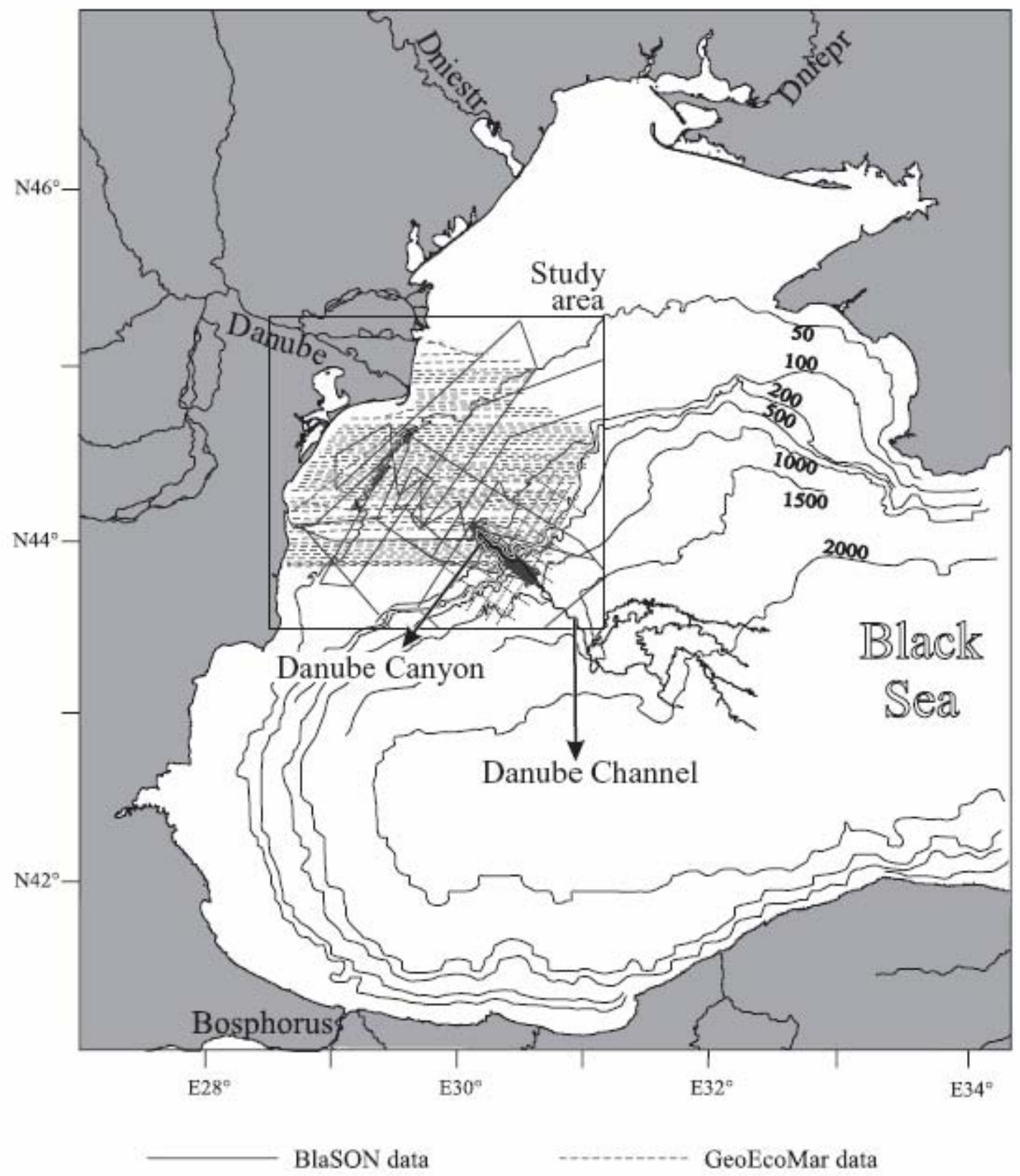

Petrom data

Fig. 1. General map of the Black Sea showing the location of the Danube Canyon. The position of the Danube Channel (the youngest channel-levee system of the Danube Fan) is also figured. 


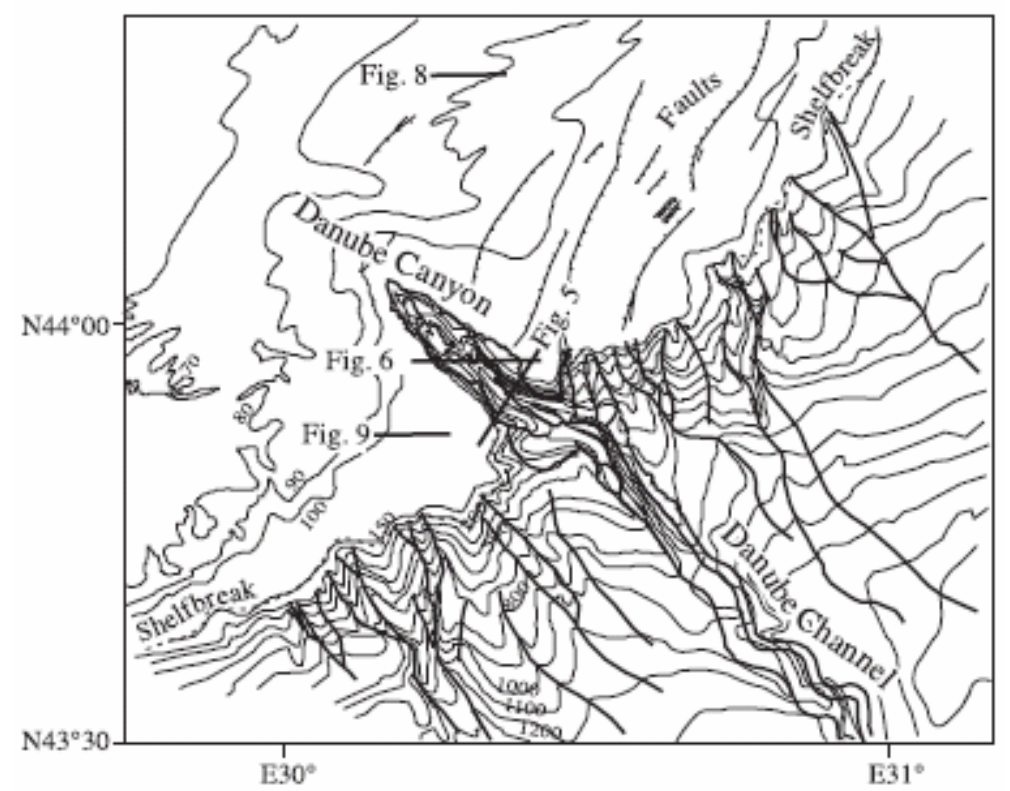

Fig. 2. Morphologic map of the north-western Black Sea margin in the Danube Canyon area. The Danube canyon is deeply incised into the shelf, whereas the other canyons terminate at the shelfbreak. The Danube Canyon continues on the slope as a major channel-levee system: the Danube channel. On the shelf margin northward of the Danube Canyon, the seafloor is affected by recent faults, up to $15 \mathrm{~m}$ throw. 


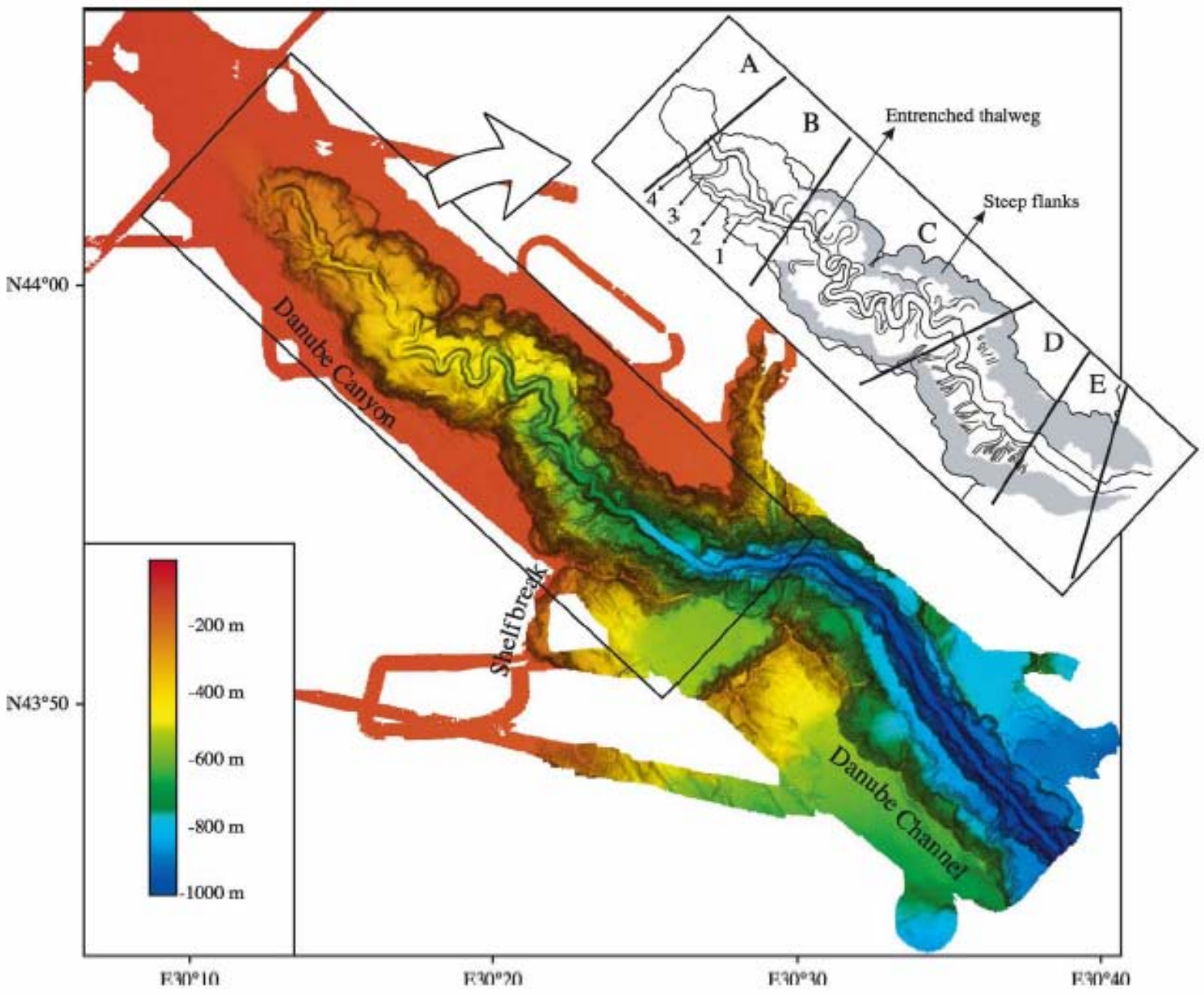

Fig. 3. Bathymetric 3D map of the Danube Canyon, obtained from EM1000 data. The inset box shows a schematic representation of the canyon morphology, and the segments A to E separated along the canyon. Distinct paths of the thalweg in segment B are numbered 1 to 4 . Shaded areas mark the steep canyon flanks. 


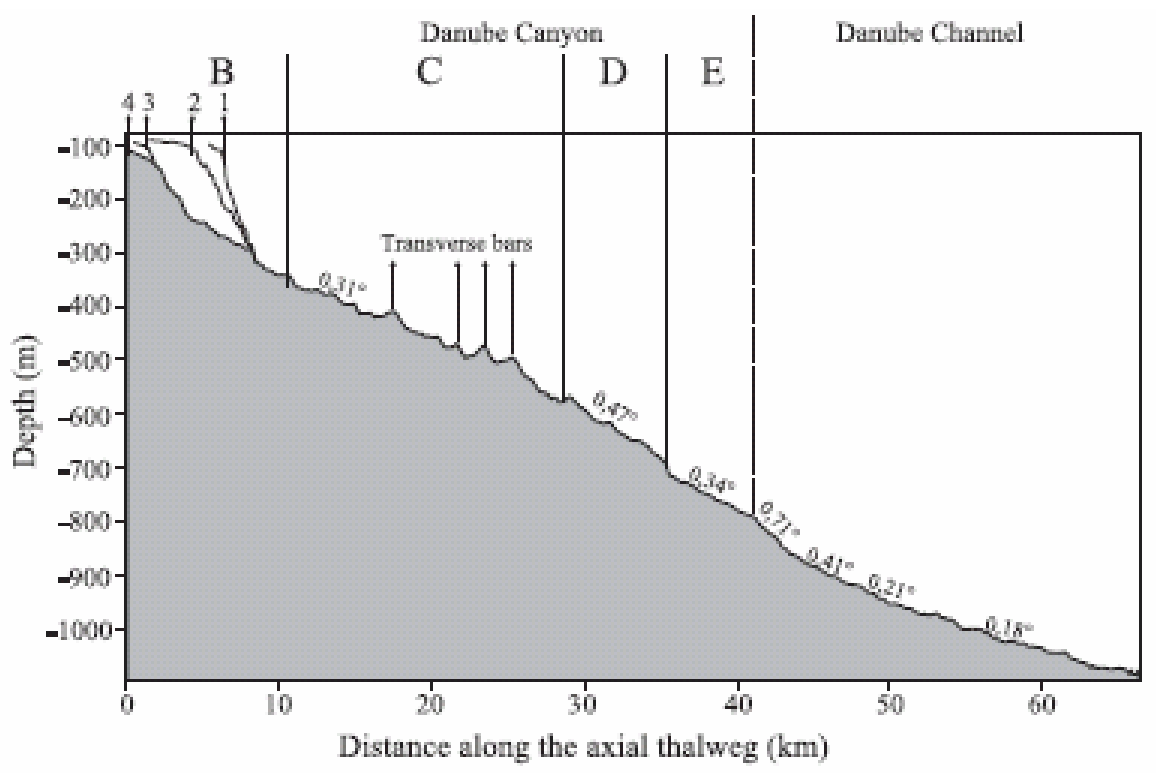

Fig. 4. Longitudinal depth profile along the axial thalweg of the Danube Canyon/Channel obtained from EM1000 data. Segments B to E show distinct thalweg gradients. Mean slope gradients are indicated for each segment. In segment B, 1 to 4 represent different paths of the thalweg. Meanders of the thalweg in segment $C$ are associated with the lowest gradient zone, whereas part of the sediment is deposed inside the thalweg as transverse bars. Transition from the canyon to the channel-levee system is marked by a knickpoint.

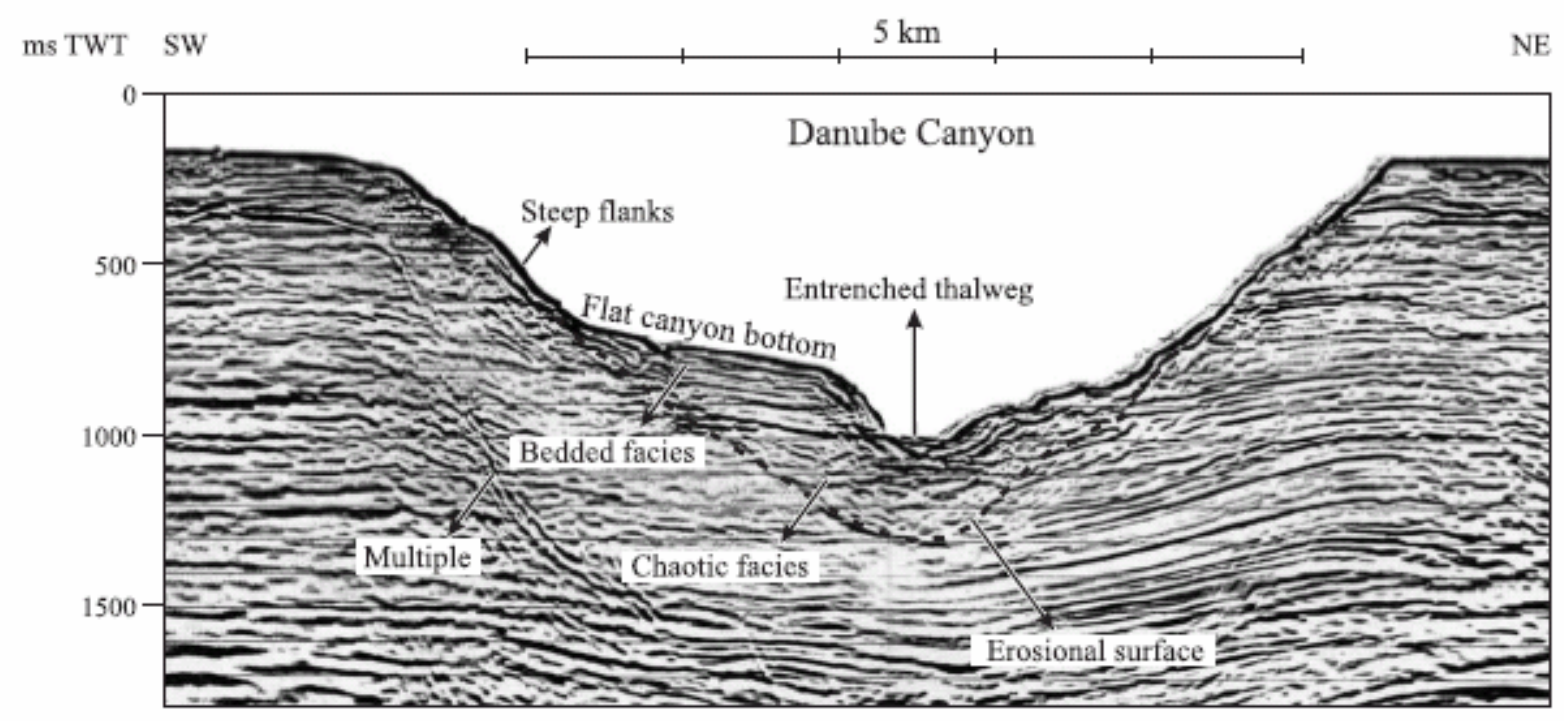

Fig. 5. Sedimentary structure of the Danube Canyon (part of seismic industrial profile P941S-44, location in Fig. 2). The line is situated across segment $D$. Canyon steep flanks are in prolongation of an ancient erosional surface (marked in dashed line), documenting a previous phase of canyon development. The infill consists of a chaotic seismic facies overlain by a high amplitude bedded facies, and is incised by the modern thalweg. 


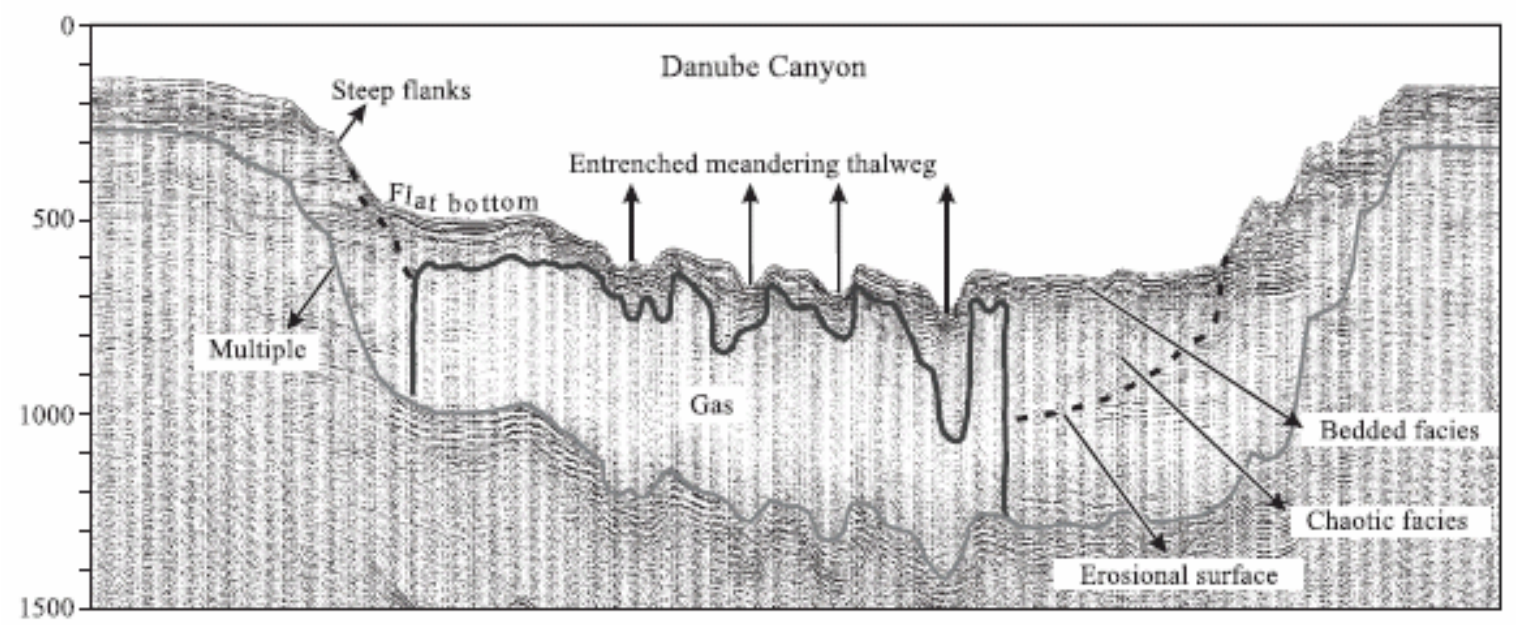

Fig. 6. Sedimentary structure of the Danube Canyon (part of 24-channel seismic reflection profile b053, location in Fig. 2). The profile is situated across segment C. Dashed line marks an ancient erosional surface in prologation of the modern flanks. Canyon fill is partially masked by gas. The meandering axial entrenched thalweg is crossed several times.

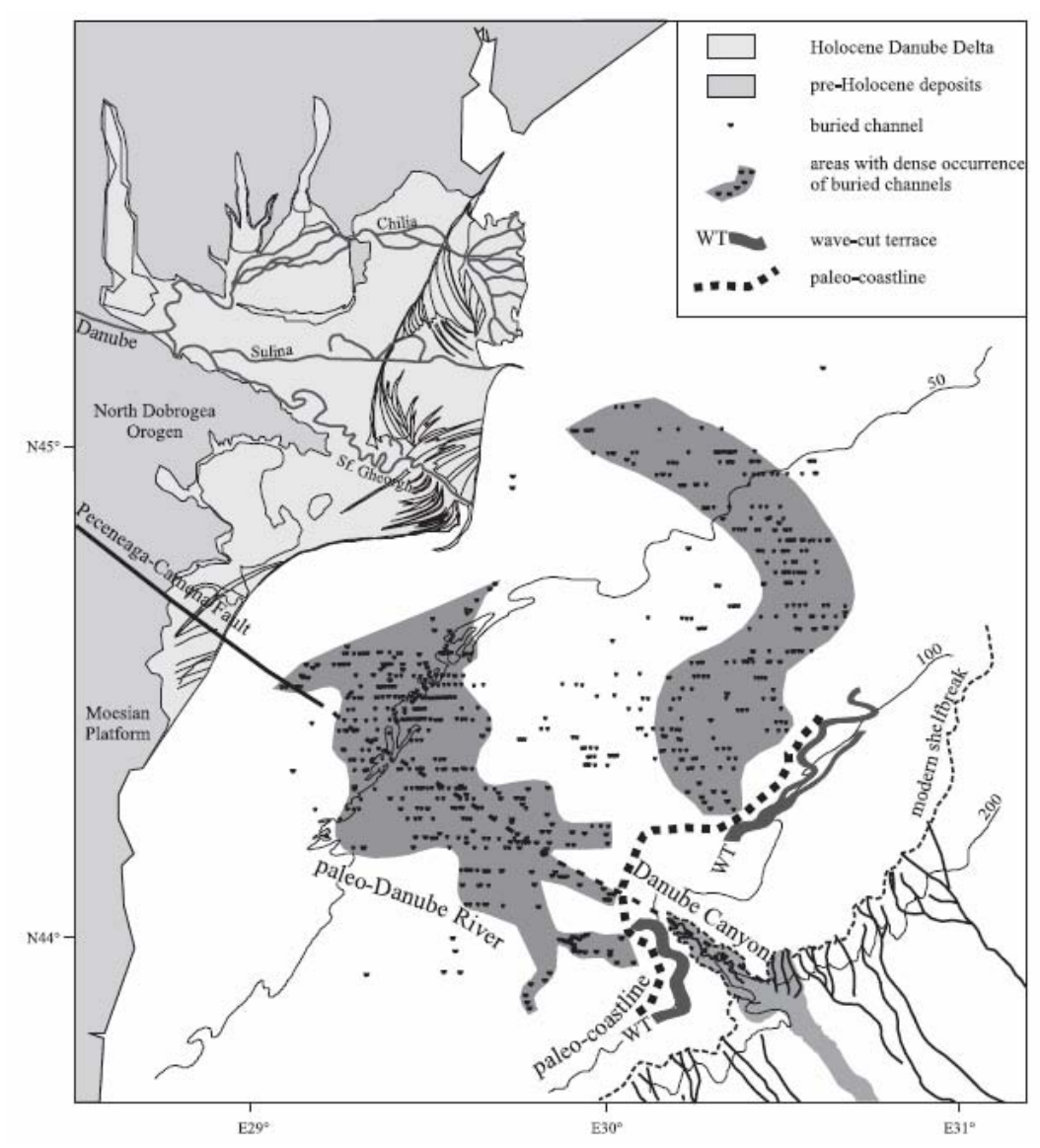

Fig. 7. Paleogeographic map of the north-western Black Sea margin during the last sea-level lowstand. Individual buried channels identified on shallow seismic profiles are marked, as well as the location of the submerged wave-cut terrace (WT). Areas characterized by dense occurrence of buried channels cluster in two main paleo-drainage systems. The presumed position of the PeceneagaCamena fault is drawn after Winguth et al. (2000) and Dinu et al. (2002). In the vicinity of the modern coastline the paleo-Danube buried system is masked by extensive shallow gas in the Danube prodelta. 


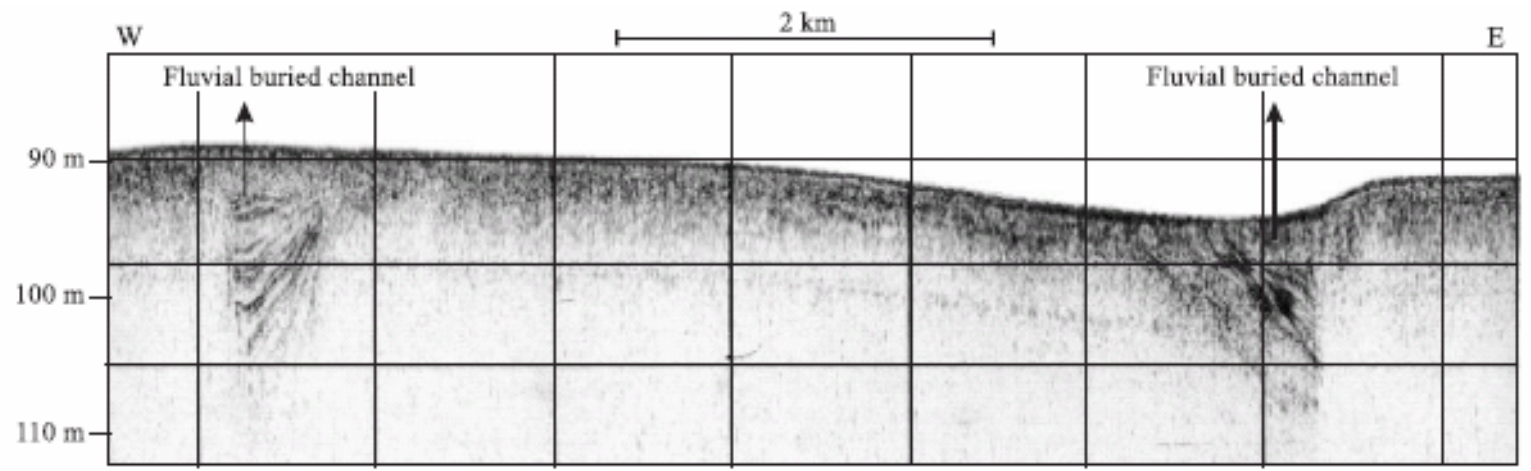

Fig. 8. Example of fluvial buried channels on the continental shelf (part of $3.5 \mathrm{kHz}$ seismic reflection profile L/81, location in Fig. 2). The asymmetrical pattern of the fill is most likely the result of lateral accretion and progressive infilling of a meandering river.

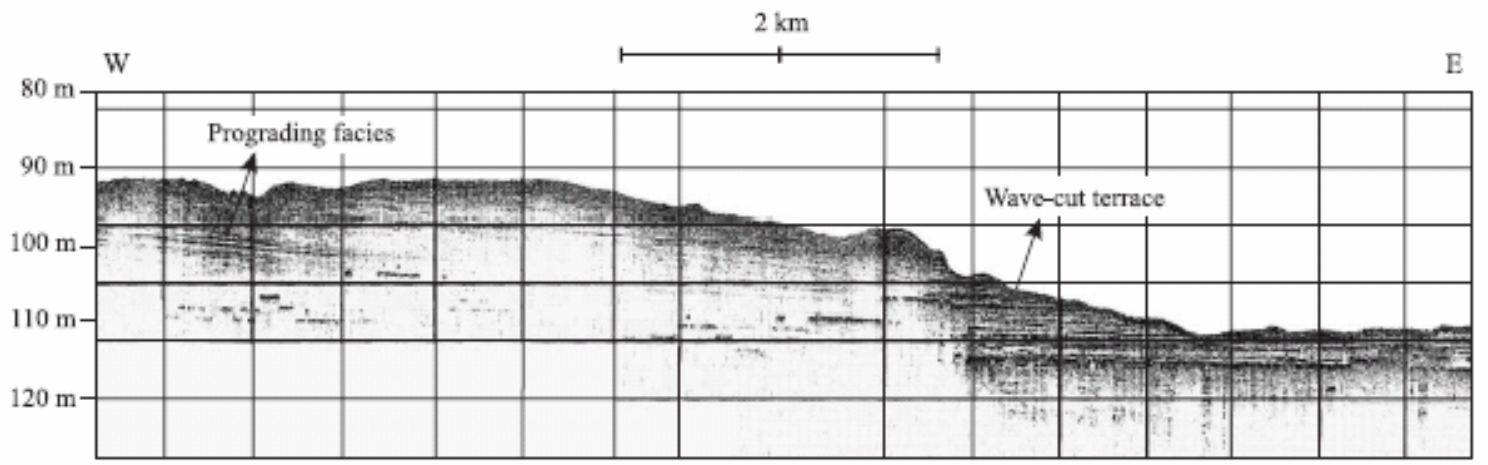

Fig. 9. Wave-cut terrace evidenced on the outer shelf (part of $3.5 \mathrm{kHz}$ seismic reflection profile $3 / 83$, location in Fig. 2). The terrace truncates the low angle clinoforms of a prograding facies. Shallow gas partially masks the sedimentary structure.

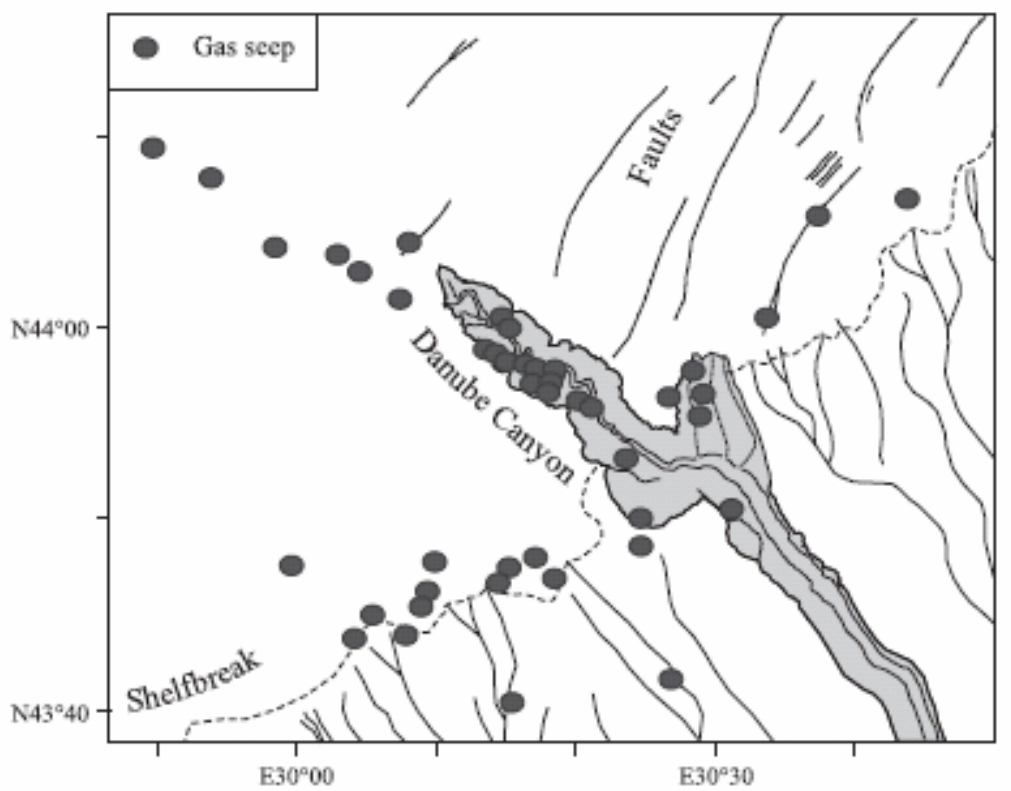

Fig. 10. Location of gas seeps (re-drawn after Egorov et al., 1998) in relation to the morphology of the canyon area. Most of the seepage areas are located along the Danube Canyon and close to the shelf edge. 